\title{
Distribution, habitat and conservation status of two threatened annual fishes (Rivulidae) from southern Brazil
}

\author{
Matheus Vieira Volcan*, Ândrio Cardozo Gonçalves, Luis Esteban Krause Lanés \\ Instituto Pró-Pampa (IPPampa), Ichthyology Laboratory, Gomes Carneiro Street \#1043, Centro, Pelotas 96010-610, Brazil
}

\begin{abstract}
This study presents information on the distribution of Austrolebias cyaneus and A. juanlangi, 2 annual fish species of southern Brazil considered threatened. Furthermore, data are provided on the conservation status of these species and their habitat characteristics to assist in the development of management plans and in the selection of priority areas for conservation of annual fishes in southern Brazil. A total of 6 populations of A. cyaneus and 3 populations of A. juanlangi were sampled from small ponds less than $1000 \mathrm{~m}^{2}$ in surface area. We sampled 104 specimens of A. cyaneus, distributed in the municipality of Rio Pardo and Minas do Leão in the basins of the Francisquinho, Capivari, and Dom Marcos streams, Jacuí River basin. A. juanlangi was recorded in the municipalities of Herval, Hulha Negra, and Pedras Altas, Jaguarão River basin, with 53 specimens being captured. At the sampling sites, the main threat to both species was rice cultivation. All pools were altered, isolated, and in an advanced state of degradation as a result of this monoculture. The restricted distribution area of the annual fishes and the advanced state of degradation and habitat loss of the wetlands sampled in this study justify the creation of conservation units in the areas of occurrence of Rivulidae species.
\end{abstract}

KEY WORDS: Austrolebias cyaneus · Austrolebias juanlangi · Endemic $\cdot$ Endangered species · Rivulidae $\cdot$ Wetlands $\cdot$ Habitat loss

\section{INTRODUCTION}

The family Rivulidae (Cyprinodontiformes, Aplocheiloidei) currently comprises 27 genera and 324 possible valid species distributed in southern North America, Central America, and South America, and it is one of the largest families of freshwater fishes from the Neotropical region. Brazil has the greatest diversity, with about 200 species recorded and $60 \%$ of the total Rivulidae (Costa 2008). Despite the species richness of Rivulidae in Brazil, the family is considered the most endangered of all fish in the country (Rosa \& Lima 2008). The causes vary according to the region of the country and are mostly related to population density and economic activity.
In the state of Rio Grande do Sul, 26 species of Rivulidae have been recorded, 20 of which belong to the genus Austrolebias (Cheffe et al. 2010, Volcan et al. 2010a), 5 to Cynopoecilus (Costa 2002a), and 1 to Rivulus (Costa \& Lanés 2009). The main cause of habitat loss for annual fishes in the state is rice farming, which usually occurs in low areas and floodplains near rivers and streams precisely where there is a greater concentration of wetlands with rivulids (Reis et al. 2003, Rosa \& Lima 2008). Of all freshwater fishes threatened with extinction in the state, about $40 \%$ are annual fishes (Reis et al. 2003). Despite the human threats and imminent risk of extinction of some species, few studies have focused on the distribution and conservation of this group of fishes (Costa 2002b, Reis et al. 2003, Volcan et al. 2009, 2010a,b,c,d). 
The advanced stage of loss and fragmentation of wetlands in southern Brazil (Maltchik et al. 2004, Guadagnin et al. 2005, Stenert et al. 2008) highlights the urgency of adopting conservation and protection measures in these environments. Locating and mapping the distribution and describing their habitats are critical for the development of strategies that promote conservation. Given the high level of endemism of the fish and their level of imperilment, the annual fishes are in urgent need of conservation assistance.

This paper presents current information on the distribution, abundance, and habitat of the annual fishes Austrolebias cyaneus (Amato, 1986) and A. juanlangi Costa, Cheffe, Salvia and Litz, 2006. These data were collected to assist in the development of management plans and in the selection of priority areas for conservation of endangered species of Rivulidae in southern Brazil.

\section{MATERIALS AND METHODS}

Study area. According to the classification of IBGE (2004), the grasslands areas in the state of Rio Grande do Sul are located in 2 distinct biomes: Mata Atlântica, covering the grasslands that are located to the northeast, and the Pampa, which includes grasslands located in the central and southern half of the state. Around $65 \%$ of the territory of Rio Grande do Sul is located in the Pampa biome (IBGE 2004). Several areas of this biome have been prioritized for conservation based on species richness, endemism, and abiotic factors (MMA 2002). Nevertheless, this biome is poorly represented by protected areas (Overbeck et al. 2007).

The study region was the Depressão Central, located in the Pampa biome, in the central and southern half of the state. This region has a slightly undulating topography with wide floodplains. The average altitude is $100 \mathrm{~m}$, while the maximum altitude is between 250 and $300 \mathrm{~m}$. The Depressão Central region is the warmest area in the state, and, according to the Köeppen classification, it has a subtropical climate, with annual precipitation around $1600 \mathrm{~mm}$. However, the average rainfall varies markedly over the year and is more concentrated during the cooler months (July to November), when annual fishes are also reported in southern Brazil (Costa 2006).

Fish sampling. As part of a research project conducted by the Ichthyology Laboratory of the Instituto Pró-Pampa to investigate the ecology, distribution, and conservation of annual fishes in the Pampa biome in southern Brazil (Annual Fishes of Pampa project), 4 sampling campaigns were performed between September and November 2009.
To identify the location of wetlands, maps and aerial images were analyzed. Based on the results of the analysis, field studies were carried out to map the sites with Rivulidae. Fish were captured with a Dshaped hand net $(60 \times 50 \mathrm{~cm}, 2 \mathrm{~mm}$ mesh $)$. To determine the abundance of each species in wetlands, 15 sweeps of $1 \mathrm{~m}$ were randomly performed at each sampling site.

The captured specimens were measured (mm), recorded, and returned to their natural habitat. Representative specimens were fixed in $10 \%$ formalin and stored in $70 \%$ alcohol. Since both species (Austrolebias cyaneus and $A$. juanlangi) have restricted distributions and belong to a morphologically homogeneous group (Costa 2002c, 2006), representative specimens were measured with the aid of digital calipers $(0.01 \mathrm{~mm})$ to verify whether they were consistent with the findings of relevant taxonomic studies (Costa 2006). Voucher specimens were deposited in the ichthyological collection of the Museu de Ciência e Tecnologia da PUCRS (MCP).

At the site of capture of annual fishes, GPS coordinates, altitude, and wetland area were estimated, and the characteristics of habitat and the physical and chemical parameters of water were assessed with the aid of portable devices; $\mathrm{pH}$, dissolved oxygen $\left(\mathrm{mg} \mathrm{l}^{-1}\right)$, conductivity $\left(\mu \mathrm{S} \mathrm{cm}^{-1}\right)$, temperature $\left({ }^{\circ} \mathrm{C}_{i}\right.$ Quimis Instruments), transparency (Secchi disk), and depth (cm) were recorded.

Data analysis. Correlations between environmental variables were tested using Pearson's coefficient. Stepwise multiple regression with backward selection was used to ascertain the extent to which the environmental variables (area, altitude, water temperature, depth, conductivity, $\mathrm{pH}$, and dissolved oxygen) and richness and abundance of non-annual fishes explained patterns of abundance of Austrolebias species. The analyses were performed using Biostat 5.0 after confirming that data satisfied the statistical assumptions of the parametric tests used.

\section{RESULTS}

In total, we sampled 9 wetlands with annual fish occurrence, 6 populations of Austrolebias cyaneus and 3 of A. juanlangi (Fig. 1). A. cyaneus is distributed in the municipalities of Rio Pardo and Minas do Leão, in the basins of the Francisquinho (MCP 45180), Capivari (MCP 45179), and Dom Marcos Streams, all sampling sites in the Jacuí River basin, Patos-Mirim Lagoon system (Fig. 2), totaling 104 specimens. In the floodplains of the Dom Marcos Stream, 1 population was sampled. In the floodplain of the Francisquinho Stream, 2 abundant populations were recorded, while in the flood- 

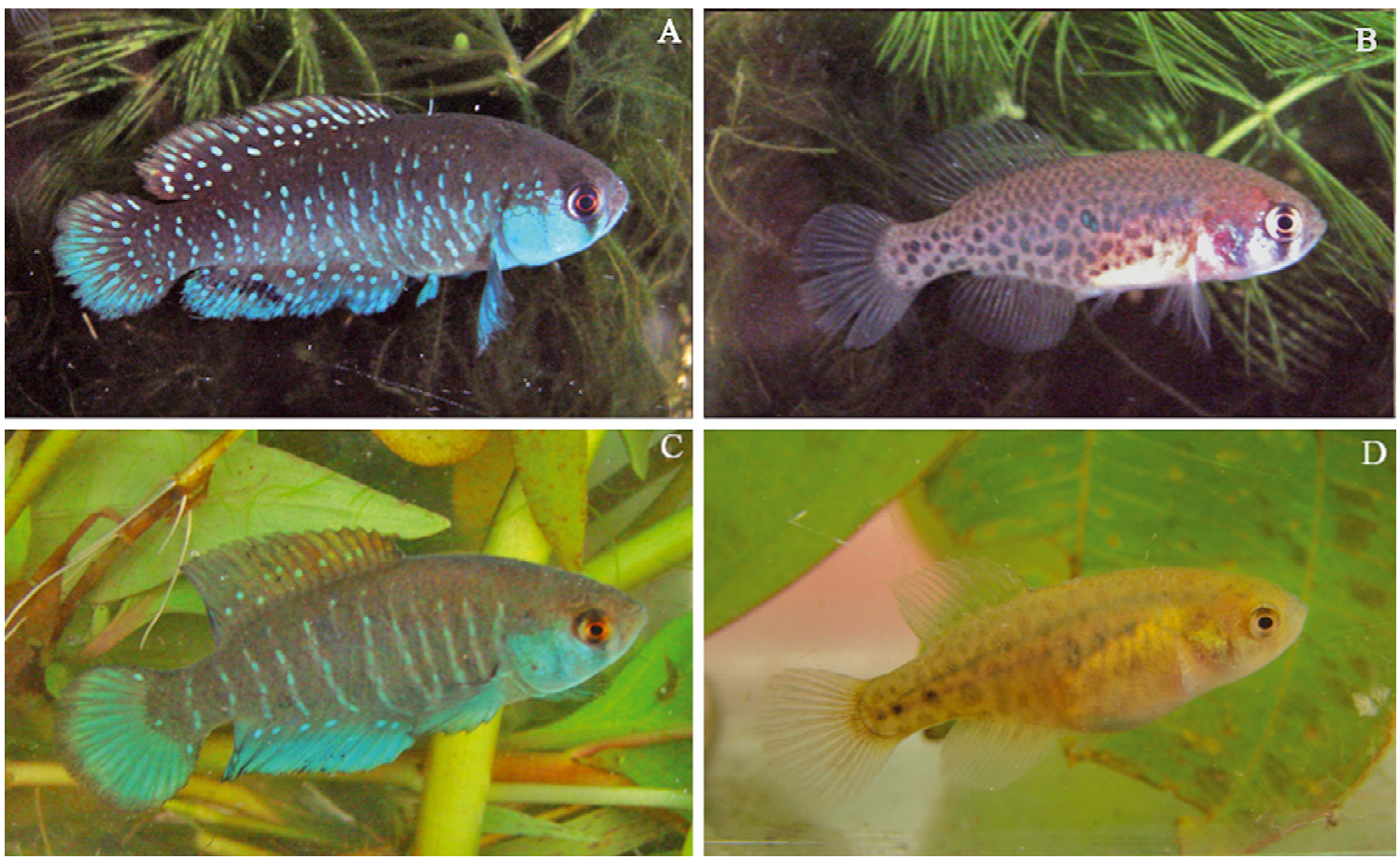

Fig. 1. Austrolebias spp. (A) Male and (B) female A. cyaneus, captured in the floodplain of Capivari Stream, Rio Pardo. (C) Male and (D) female A. juanlangi sampled in the Jaguarão River, Herval. Photos by M. V. Volcan

plains of the Capivari Stream, the occurrence of 3 populations was confirmed (Table 1).

The populations of Austrolebias juanlangi were recorded in the municipalities of Herval (MCP 45177), Hulha Negra (MCP 45178), and Pedras Altas (MCP 45181), located in the Jaguarão River basin, PatosMirim Lagoon system, and totaling 53 specimens (Table 1). Measurements of the 2 species are given in Table 2.

All sites were extremely shallow, with depths ranging from 8 to $26 \mathrm{~cm}$ (Table 3). The low value of transparency observed in the habitats of Austrolebias juanlangi (4.5 to $14 \mathrm{~cm}$ ) was not recorded in pools inhabited by $A$. cyaneus, which were completely transparent. Dissolved oxygen was the parameter with the greatest variation in wetlands with $A$. cyaneus (3.7 to $9.4 \mathrm{mg} \mathrm{l}^{-1}$ ), while conductivity showed the greatest variation in wetlands with $A$. juanlangi (59.4 to $164.9 \mu \mathrm{S} \mathrm{cm}^{-1}$; Table 3).

Sites with Austrolebias cyaneus were located at altitudes ranging between 15 and $46 \mathrm{~m}$, while A. juanlangi was recorded in highlands up to $152 \mathrm{~m}$ a.s.l. (Table 1). Both species were caught in small ponds less than $1000 \mathrm{~m}^{2}$ in size. At the sampling sites, the main threat to both species is rice cultivation, since all pools were altered, isolated, and in an advanced state of degradation. Cattle occurred at all sampling sites, which showed typical signs of grazing and trampling.
Pearson's correlation analysis demonstrated that the wetland altitude was negatively correlated with temperature $(\mathrm{r}=-0.79, \mathrm{p}=0.01)$ and positively correlated with depth $(\mathrm{r}=0.88, \mathrm{p}=0.001)$, $\mathrm{pH}$ was positively correlated with conductivity $(\mathrm{r}=0.93, \mathrm{p}=0.0002)$ and depth $(\mathrm{r}=0.72$, $\mathrm{p}=0.02)$ and negatively associated with temperature $(\mathrm{r}=$ $-0.87, \mathrm{p}=0.002$ ). Water temperature was negatively correlated with conductivity $(\mathrm{r}=-0.69, \mathrm{p}=0.03)$ and $\operatorname{depth}(\mathrm{r}=-0.77, \mathrm{p}=0.01)$. The other environmental variables were not correlated $(p>0.05)$. Stepwise multiple regression analysis showed that the models incorporating wetland area, altitude, depth, $\mathrm{pH}$, dissolved oxygen, water temperature, and conductivity failed to explain the variation in Austrolebias abundance and in the richness of fish species in the sampled wetlands ( $p>0.05)$.

Austrolebias cyaneus, despite not occurring with sympatric Rivulidae species, occurred with 8 species of non-annual fishes: Cyphocarax voga, Cheirodon ibicuhiensis, Cheirodon interruptus, Oligosarcus robustus, Rhamdia aff. quelen, Callichthys callichthys, Phalloceros caudimaculatus, and Synbranchus marmoratus. Austrolebias juanlangi was recorded only with Astyanax aff. eigenmanniorum, Cheirodon ibicuhensis, Cheirodon interruptus, and Hyphessobrycon luetkenii. Multiple linear regression analysis revealed no influence of richness and abundance of non-annual fishes on the abundance of Rivulidae ( $p>0.05)$, which were the most abundant species at all sampling sites. 


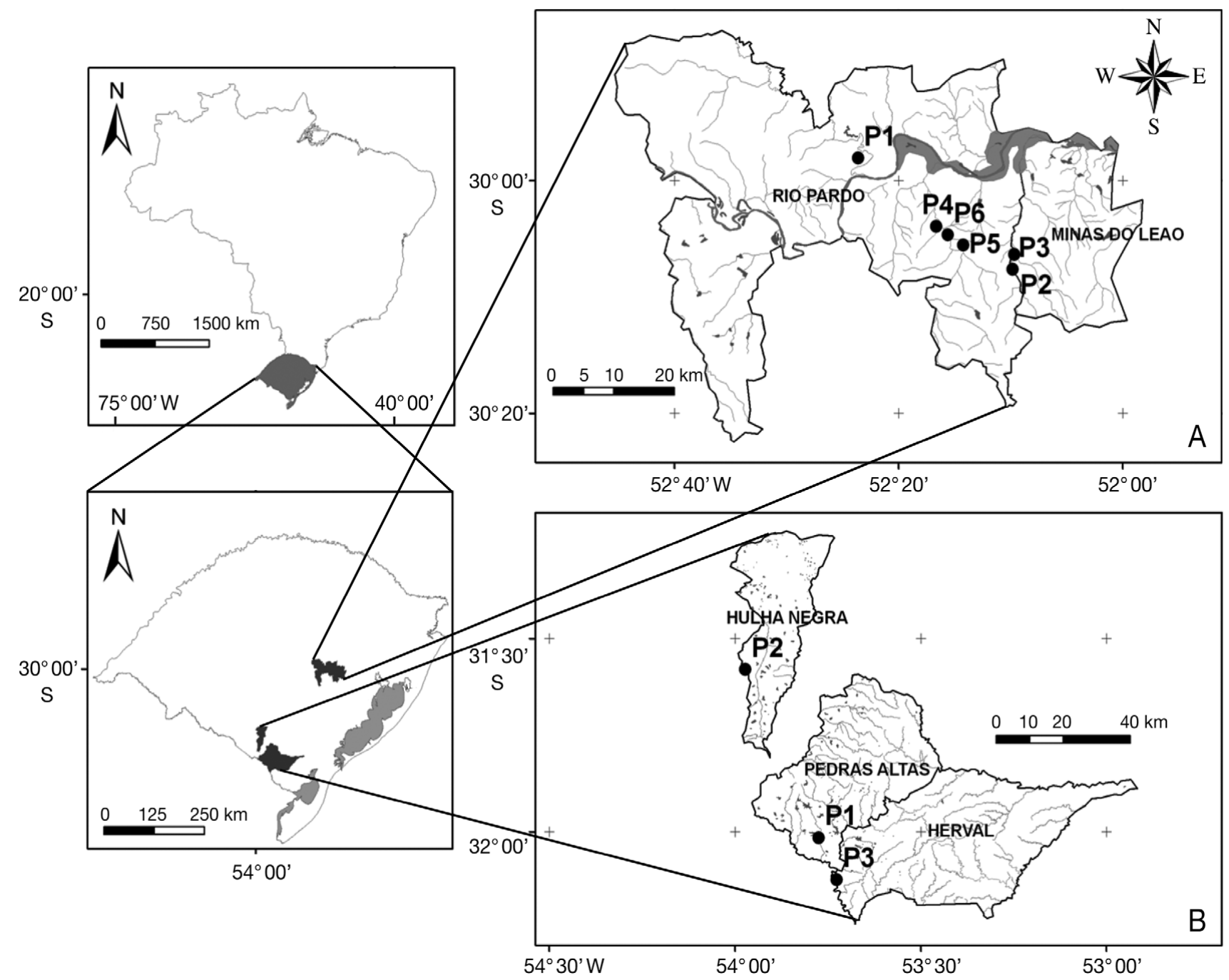

Fig. 2. Austrolebias spp. Distribution area of 2 annual Rivulidae fishes in Rio Grande do Sul, southern Brazil. (A) Location of the 6 sampling sites with A. cyaneus; (B) sampling sites with A. juanlangi. Map by M. P. Corrêa. Source: FEPAM (2005)

Table 1. Austrolebias spp. Municipality, basin, sampling sites (see Fig. 2 for locations of sites), coordinates, altitude (Alt. = meters above sea level), estimated area $\left(\mathrm{m}^{2}\right)$, abundance $(\mathrm{N})$ and standard length $(\mathrm{SL}, \mathrm{mm})$ of males and females of A. cyaneus and A. juanlangi in southern Rio Grande do Sul, Brazil

\begin{tabular}{|c|c|c|c|c|c|c|c|c|c|c|}
\hline \multirow{2}{*}{ Municipality } & \multirow[t]{2}{*}{ Basin } & \multirow[t]{2}{*}{ Site } & \multicolumn{2}{|c|}{ Coordinates } & \multirow[t]{2}{*}{ Alt. } & \multirow[t]{2}{*}{ Area } & \multicolumn{2}{|c|}{ Male } & \multicolumn{2}{|c|}{ Female } \\
\hline & & & South & West & & & $\mathrm{n}$ & SL & $\mathrm{n}$ & SL \\
\hline \multicolumn{11}{|l|}{ A. cyaneus } \\
\hline Minas do Leão & Francisquinho Stream & P1 & $30^{\circ} 06^{\prime} 24^{\prime \prime}$ & $52^{\circ} 09^{\prime} 41^{\prime \prime}$ & 39 & 800 & 9 & $21.6-22.4$ & 12 & $22.0-23.8$ \\
\hline Minas do Leão & Francisquinho Stream & P2 & $30^{\circ} 07^{\prime} 40^{\prime \prime}$ & $52^{\circ} 09^{\prime} 51^{\prime \prime}$ & 37 & 40 & 17 & $22.0-37.5$ & 13 & $18.0-23.3$ \\
\hline Rio Pardo & Capivari Stream & P3 & $30^{\circ} 03^{\prime} 59^{\prime \prime}$ & $52^{\circ} 16^{\prime} 41^{\prime \prime}$ & 15 & 200 & 3 & $21.2-30.2$ & 6 & $19.6-27.2$ \\
\hline Rio Pardo & Capivari Stream & $\mathrm{P} 4$ & $30^{\circ} 05^{\prime} 35^{\prime \prime}$ & $52^{\circ} 14^{\prime} 14^{\prime \prime}$ & 46 & 1500 & 9 & $21.0-31.6$ & 8 & $20.0-24.7$ \\
\hline Rio Pardo & Capivari Stream & P5 & $30^{\circ} 04^{\prime} 41^{\prime \prime}$ & $52^{\circ} 15^{\prime} 36^{\prime \prime}$ & 26 & 2000 & 2 & $29.4-31.6$ & 4 & $22.4-23.3$ \\
\hline Rio Pardo & Dom Marcos Stream & P6 & $29^{\circ} 58^{\prime} 05^{\prime \prime}$ & $52^{\circ} 23^{\prime} 37^{\prime \prime}$ & 18 & 300 & 7 & $23.2-31.5$ & 14 & $23.0-31.8$ \\
\hline $\begin{array}{l}\text { A. juanlangi } \\
\text { Pedras Altas }\end{array}$ & Jaguarão River & P1 & $32^{\circ} 00^{\prime} 56^{\prime \prime}$ & $53^{\circ} 46^{\prime} 28^{\prime \prime}$ & 84 & 700 & 6 & $31.5-34.7$ & 10 & $24.0-26.3$ \\
\hline Hulha Negra & Jaguarão River & $\mathrm{P} 2$ & $31^{\circ} 34^{\prime} 51^{\prime \prime}$ & $53^{\circ} 58^{\prime} 18^{\prime \prime}$ & 152 & 800 & 2 & $32.4-36.2$ & 8 & $24.8-34.0$ \\
\hline Herval & Jaguarão River & P3 & $32^{\circ} 07^{\prime} 28^{\prime \prime}$ & $53^{\circ} 43^{\prime} 34^{\prime \prime}$ & 75 & 1500 & 11 & $21.8-26.9$ & 16 & $19.3-22.7$ \\
\hline
\end{tabular}


Table 2. Austrolebias spp. Morphometric data (n in parentheses)

\begin{tabular}{|lllll|}
\hline \multirow{2}{*}{ Measurement } & \multicolumn{2}{c}{ A. cyaneus } & \multicolumn{2}{c|}{ A. juanlangi } \\
& Males (3) & Females (2) & Males (4) & Females (5) \\
\hline $\begin{array}{l}\text { Standard length } \\
\text { (SL, mm) }\end{array}$ & $29.3-31.3$ & $22.2-23.6$ & $23.9-34.1$ & $22.6-29.7$ \\
Body depth (\%SL) & $36.1-38.7$ & $36.4-38.7$ & $32.9-35.7$ & $33.2-35.9$ \\
Caudal peduncle depth & $15.4-17.3$ & $14.9-16.1$ & $14.7-15.8$ & $12.8-14.4$ \\
(\%SL) & & & & \\
Pre-dorsal length (\%SL) & $47.9-52.0$ & $59.7-62.2$ & $48.9-54.4$ & $56.7-63.7$ \\
Pre-pelvic length (\%SL) & $40.6-42.0$ & $48.3-55.4$ & $43.1-48.1$ & $49.6-54.2$ \\
Length of dorsal fin base & $41.2-43.5$ & $31.1-33.9$ & $38.9-43.4$ & $23.4-29.6$ \\
$\quad$ & & & & \\
(\%SL) & & & & \\
(\%SL) & & & & \\
Caudal fin length (\%SL) & $21.1-24.3$ & $22.5-24.6$ & $21.4-26.4$ & $23.3-26.5$ \\
Pectoral fin length (\%SL) & $21.7-25.3$ & $22.5-24.3$ & $20.2-23.0$ & $18.3-23.5$ \\
Head length (HL, mm) & $32.3-36.7$ & $33.8-34.3$ & $26.2-32.3$ & $28.9-31.9$ \\
Head depth (\%HL) & $86.4-101.0$ & $95.1-101.3$ & $86.1-109.5$ & $91.1-98.7$ \\
Head width (\%HL) & $53.6-60.6$ & $64.0-65.4$ & $65.3-77.6$ & $63.9-73.4$ \\
\hline
\end{tabular}

Table 3. Environmental variables related to physical-chemical characteristics of the wetlands with annual fishes in southern Brazil

\begin{tabular}{|c|c|c|c|c|c|c|}
\hline \multirow{2}{*}{ Water parameter } & \multicolumn{3}{|c|}{ Austrolebias cyaneus } & \multicolumn{3}{|c|}{ Austrolebias juanlangi } \\
\hline & Min. & Max. & Mean \pm SD & Min. & Max. & Mean \pm SD \\
\hline $\begin{array}{l}\text { Dissolved oxygen } \\
\left(\mathrm{mg} \mathrm{l}^{-1}\right)\end{array}$ & 3.7 & 9.4 & $7.2 \pm 2.4$ & 5.9 & 8.2 & $6.9 \pm 0.8$ \\
\hline $\mathrm{pH}$ & 5.1 & 5.5 & $5.2 \pm 0.2$ & 6.11 & 7.16 & $6.61 \pm 0.4$ \\
\hline Temperature $\left({ }^{\circ} \mathrm{C}\right)$ & 25.3 & 33.4 & $27.7 \pm 3.8$ & 14.3 & 19.1 & $16.2 \pm 1.9$ \\
\hline $\begin{array}{l}\text { Conductivity } \\
\left.(\mu \mathrm{S} \mathrm{cm})^{-1}\right)\end{array}$ & 33.2 & 45.8 & $38.2 \pm 4.7$ & 59.4 & 164.9 & $117.6 \pm 46.1$ \\
\hline Depth (cm) & 8.0 & 14.0 & $10.8 \pm 2.6$ & 8.0 & 26.0 & $18.5 \pm 6.1$ \\
\hline Transparency (cm) & 8.0 & 14.0 & $10.8 \pm 2.6$ & 4.5 & 10.0 & $6.7 \pm 1.8$ \\
\hline
\end{tabular}

While describing Austrolebias juanlangi, Costa (2006) distinguished it from $A$. affinis, whose distribution was restricted to Uruguay. Nevertheless, Rosa \& Lima (2008) included A. affinis in the list of endangered fish species in Brazil, but failed to include A. juanlangi among the species of Brazilian fauna in danger of extinction. The suppression and changes observed in its biotopes and the restricted distribution area of the species justifies its inclusion in the next list of species at risk of extinction in Brazil. In this context, $A$. cyaneus is included in the Red Book of Endangered Species of Fauna of Rio Grande do Sul and Brazil (Reis et al. 2003, Rosa \& Lima 2008).

The presence of rice culture at all sampling sites with annual fishes recorded in the present study is considered by many authors to be the main cause of decline of populations of Austrolebias in Brazil (Costa 2002b, Reis et al. 2003, Rosa \& Lima 2008, Volcan et al. 2009, 2010a,b,c,d). Besides these threats, there is much speculation in the region regarding exotic forestry, an aspect that deserves consideration in the implementation of future projects to prevent the loss of the remaining biotopes.

As observed in the present study, the DISCUSSION

Austrolebias cyaneus is endemic to the lower Jacuí River, Patos Lagoon system, and prior to this study, only a single population had been recorded, in the floodplain of the Dom Marcos Stream, municipality of Rio Pardo, Rio Grande do Sul (Costa 2006). Based on the fish captured in this study, we extend the distribution of A. cyaneus to a new municipality (Minas do Leão) and 5 new populations, divided into 2 new subbasins (Capivari and Francisquinho Streams).

The annual fish Austrolebias juanlangi has been recorded in Brazil in only 3 municipalities: Aceguá, Bagé, and Jaguarão in areas in the floodplains of the Jaguarão River, the Patos-Mirim Lagoon system, and the Negro River in the Uruguay River basin (Costa 2006). In Uruguay, the species has been recorded in the Taquarí River, and some populations were found in the Negro River (Costa 2006). Capture of specimens from 3 populations has expanded the distribution of this species to the municipalities of Herval, Hulha Negra, and Pedras Altas, which are all part of the Jaguarão River basin. small size of wetlands was also recorded by Maltchik et al. (2003), who inventoried about 3500 wetlands in southern Brazil and found that around $70 \%$ of them were less than $1 \mathrm{~km}^{2}$ in size. This factor is probably a reflection of years of suppression, mainly caused by rice culture. In their study of wetlands of the coastal region of Rio Grande do Sul, Maltchik et al. (2010), observed that most areas are fragmented and small, and that although presenting lower biological richness than relatively larger wetlands, they have a different species composition, suggesting that small wetlands deserve attention, especially in regions where agriculture and forestry are expanding.

According to Errea \& Danulat (2001) and Arenzon et al. (2002), annual fishes are generally exposed to marked fluctuations in abiotic conditions in their natural habitats, requiring several adjustments related to their life cycle. Survival under highly variable environmental conditions such as drought stress, low oxygen levels, and wide temperature fluctuations are typical characteristics of this group (Errea \& Danulat 2001). In this study, multiple linear regression analysis revealed no relationship between 
the environmental variables and abundance of annual fishes. Austrolebias species are considered rare (Nogueira et al. 2010), and some species are only known for their type locality (Costa 2008). It is possible that due to the low number of samples and wide variation in environmental conditions, the parameters used to characterize the wetlands could not explain the variation in the abundance of annual fishes.

The abundance and richness of non-annual fishes recorded in the present study did not influence the abundance of Austrolebias. The co-occurrence of these species (annual and non-annual fishes) was reported in other studies in southern Brazil and Uruguay (VazFerreira et al. 1966, Quintela et al. 2007). The coexistence of different species in temporary pools may likely be explained by the connection of water bodies during the rainy season (Vaz-Ferreira et al. 1966, Errea \& Danulat 2001). All species of sympatric occurrence with Rivulidae recorded here are common to the Patos Lagoon system (Malabarba 1989, Reis et al. 2003).

According to Rosa \& Lima (2008), because the species of Austrolebias were recorded in small ponds like those mentioned in this study, the protection of relatively small areas could ensure the preservation of the species. However, according to Volcan et al. (2010b,c), fragmentation and habitat loss prevent the connection of wetlands inhabited by Rivulidae and dispersal of species in floodplains. Thus, according to Volcan et al. (2010b,c), besides protecting their restricted habitats, it is necessary to establish and create large protected areas, mainly along river corridors and associated wetlands, such as the Jacuí and Jaguarão River basins, in order to enable connectivity and dispersal populations of annual fishes, assisting in their conservation.

Finally, none of the captured species occurs in protected areas. These species are endemic to Pampa (Costa 2006), and this biome is in general scarcely represented by protected areas, being considered neglected compared to other biomes of Brazil (Overbeck et al. 2007). Accordingly, areas with records of Rivulidae species could provide support for defining priority areas for the conservation of wetlands and biota that depend on these threatened ecosystems in southern Brazil.

Acknowledgements. We thank CMBio for issuing the collection license (authorization process number 18334-1) and Michel P. Corrêa for preparing Fig. 1. This paper was improved by the comments of 2 anonymous reviewers.

\section{LITERATURE CITED}

Arenzon A, Lemos CA, Bohrer MBC (2002) The influence of temperature on the embryonic development of the annual fish Cynopoecilus melanotaenia (Cyprinodontiformes: Rivulidae). Braz J Biol 62:743-747
Cheffe MM, Volcan MV, Lanés LEK (2010) Pisces, Cyprinodontiformes, Rivulidae, Austrolebias vazferreirai (Berkencamp, Etzel, Reichert and Salvia): new species record from Brazil. Check List 6:592-593

Costa WJEM (2002a) The annual fish genus Cynopoecilus (Cyprinodontiformes: Rivulidae): taxonomic revision, with descriptions of four new species. Ichthyol Explor Freshw 13:11-24

Costa WJEM (2002b) Peixes anuais brasileiros: diversidade e conservação. UFPR, Curitiba

Costa WJEM (2002c) The Austrolebias alexandri species group: a taxonomical revision of an annual fish clade (Cyprinodontiformes: Rivulidae) in southern Brazil. Comun Mus Ciên Tec PUCRS 15:87-111

Costa WJEM (2006) The South American annual killifish genus Austrolebias (Teleostei: Cyprinodontiformes: Rivulidae): phylogenetic relationships, descriptive morphology and taxonomic revision. Zootaxa 1213:1-162

Costa WJEM (2008) Catalog of aplocheiloid killifishes of the word. Reproarte, Rio de Janeiro

Costa WJEM, Lanés LEK (2009) Rivulus riograndensis, a new aplocheiloid killifish from southern Brazil (Cyprinodontiformes: Rivulidae). Ichthyol Explor Freshw 20:91-95

Errea A, Danulat E (2001) Growth of the annual fish Cynolebias viarius (Cyprinodontiformes), in the natural habitat compared to laboratory conditions. Environ Biol Fishes 61: 261-268

FEPAM (Fundação Estadual de Proteção Ambiental) (2005) Biblioteca digital. Arquivos digitais para uso em SIG. Base cartográfica digital do RS 1:250.000. Available at www.fepam.rs.gov.br/biblioteca/geo/bases_geo.asp.

Guadagnin DL, Peter AS, Perello LFC, Maltichik L (2005) Spatial and temporal patterns of waterbird assemblages in fragmented wetlands of southern Brazil. Waterbirds 28: 261-272

IBGE (Instituto Brasileiro de Geografia e Estatística) (2004) Mapa da vegetação do Brasil e mapa de biomas do Brasil. IBGE, Brasília. Available at www.ibge.gov.br

Malabarba LR (1989) Histórico sistemático e lista comentada das espécies de peixes de água doce do Sistema Laguna dos Patos, Rio Grande do Sul, Brasil. Comun Mus Ciên Tec PUCRS Ser Zool 2:107-190

Maltchik L, Schneider E, Becker G, Escobar A (2003) Inventory of wetlands of Rio Grande do Sul (Brazil). Pesqui Bot 53:89-100

Maltchik L, Rolon AS, Guadagnin D, Stenert C (2004) Wetlands of the Rio Grande do Sul, Brazil: a classification with emphasis on their plant communities. Acta Limnol Bras 16:137-151

Maltchik L, Lanés LEK, Stenert C, Medeiros E (2010) Speciesarea relationship and environmental predictors of fish communities in coastal freshwater wetlands of southern Brazil. Environ Biol Fishes 88:25-30

MMA (Ministério do Meio Ambiente) (2002) Biodiversidade brasileira - avaliação e identificação de áreas e ações prioritárias para conservação, utilização sustentável e repartição de benefícios da biodiversidade brasileira. MMA/ SBF, Brasília

> Nogueira C, Buckup PA, Menezes NA, Oyakawa OT, Kasecker TP, Neto MBR, Silva JMC (2010) Restrictedrange fishes and the conservation of Brazilian freshwaters. PLoS ONE 5:e11390

> Overbeck GE, Müller SC, Fidelis A, Pfadenhauer J and others (2007) Brazil's neglected biome: the South Brazilian Campos. Perspect Plant Ecol Evol Syst 9:101-116

Quintela FM, Porciuncula RA, Condini MVL, Vieira JP, Loebmann D (2007) Composição da ictiofauna durante o 
período de alagamento em uma mata paludosa da planície costeira do Rio Grande do Sul, Brasil. Pan Am J Aquat Sci 2:191-198

Reis RE, Kullander SO, Ferraris CJ (2003) Check list of the freshwater fishes of South and Central America. EdiPUCRS, Porto Alegre

Rosa RS, Lima FCT (2008) Peixes. In: Machado ABM, Drummond GM, Paglia AP (eds) Livro vermelho da fauna brasileira ameaçada de extinção. Ministério do Meio Ambiente, Brasília, p 8-258

Stenert C, Bacca RC, Mostardeiro CC, Maltchik L (2008) Environmental predictors of macroinvertebrate communities in coastal wetlands of southern Brazil. Mar Freshw Res 59:540-548

Vaz-Ferreira R, Sierra de Soriano B, Señorans JS (1966) Integracion de la fauna de vertebrados en algunas masas de agua dulce temporales del Uruguay. Compend Trab Dep Zool Vertebr 25:1-16

Volcan MV, Lanés LEK, Gonçalves AC (2009) Threatened

Editorial responsibility: Steven Cooke, Ottawa, Ontario, Canada fishes of the world: Austrolebias nigrofasciatus Costa and Cheffe 2001 (Cyprinodontiformes, Rivulidae). Environ Biol Fishes 86:443-444

Volcan MV, Lanés LEK, Gonçalves, AC, Cheffe MM (2010a) First record of annual killifish Austrolebias melanoorus (Amato, 1986) (Cyprinodontiformes, Rivulidae) from Brazil, with data on habitat and conservation. J Appl Ichthyol doi:10.1111/j.1439-0426.2010.01626.x

Volcan MV, Lanés LEK, Gonçalves AC (2010b) Threatened fishes of the world: Austrolebias univentripinnis Costa and Cheffe 2005 (Cyprinodontiformes, Rivulidae). Environ Biol Fishes 87:319-320

Volcan MV, Lanés LEK, Gonçalves AC (2010c) Pisces, Cyprinodontiformes, Rivulidae, Austrolebias periodicus (Costa, 1999): distribution extension in State of Rio Grande do Sul, southern Brazil. Check List 6:234-236

Volcan MV, Lanés LEK, Cheffe MM (2010d) Distribuiçao e conservação de peixes anuais (Cyprinodontiformes, Rivulidae) no município do Chui, sul do Brasil. Biotemas 23:51-58

Submitted: May 11, 2010; Accepted: October 16, 2010 Proofs received from author(s): December 22, 2010 